\title{
Variations in behavioural patterns between Lemur catta groups living in different forest types: implications for conservation
}

\author{
Nicholas Ellwanger ${ }^{1, *}$, Lisa Gould ${ }^{2}$ \\ ${ }^{1}$ Department of Anthropology, University of Texas at San Antonio, San Antonio, Texas 78249, USA \\ ${ }^{2}$ Department of Anthropology, University of Victoria, Victoria, British Columbia V8W 3P5, Canada
}

\begin{abstract}
Implementing effective primate conservation strategies requires knowledge of species' ecological and behavioural parameters. The protection of all habitat types required for preserving viable dispersion and gene flow between disparate populations necessitates a thorough understanding of the behavioural flexibility of a species. Ring-tailed lemurs Lemur catta inhabit a plethora of habitats throughout southern Madagascar but, hitherto, research has been restricted primarily to riverine gallery forests. The present study presents comparative data on the activity budgets and foraging behaviour of $2 \mathrm{~L}$. catta groups living in different habitats at Berenty Reserve, Madagascar. Data were collected for 2 mo on groups living in a xerophytic spiny forest and a riverine gallery forest. The spiny forest group spent significantly more time in inactive behaviours compared with the gallery forest group. This strategy of apparent energy minimization allows L. catta to thermoregulate despite decreased water availability and high ambient temperatures. The spiny forest group spent significantly more time feeding on small fruits of succulent trees, which we associate with the group's significantly higher rate of feeding agonism compared with the gallery forest group. These results demonstrate the high behavioural and ecological flexibility of $L$. catta, suggesting that xerophytic spiny forests might be a vital habitat type for $L$. catta conservation efforts. Future research should advance knowledge of the resources needed to sustain L. catta populations in other xerophytic spiny forests.
\end{abstract}

KEY WORDS: Lemur catta · Spiny forest · Gallery forest · Activity budget · Behavioural flexibility

\section{INTRODUCTION}

The island of Madagascar, a hotspot of biodiversity (Myers et al. 2000), has experienced anthropogenic modification for nearly 2 millennia, but habitat destruction has recently accelerated in intensity (Green \& Sussman 1990, Casse et al. 2004). Northern and eastern rainforests have received vital research and conservation attention, but much of the endemic spiny forest of southern Madagascar is poorly understood, and thus should be a focus of future research efforts (Bodin et al. 2006). This arid eco-region, estimated to have been 5 million hectares large in 2003
(Wells 2003), is highly impacted by continual anthropogenic change, including slash and burn agriculture, charcoal production and livestock maintenance (Scott et al. 2006). Spiny forests contain a high diversity of lemurs, including members of the taxonomic families Cheirogaleidae, Lepilemuridae, Lemuridae and Indridae (Sussman 2002). Thus, the spiny forest ecoregion is a conservation focal point, and its preservation is essential to sustaining lemur diversity throughout the region.

A key species in the maintenance of spiny forests is the ring-tailed lemur Lemur catta (Bodin et al. 2006, Scott et al. 2006). L. catta are highly adaptable and 
currently range in numerous habitat types throughout southern Madagascar, including gallery forest, xerophytic forest, brush and scrub, spiny, dry deciduous forest, sub-alpine ericoid bush and rocky outcrop forest surrounded by anthropogenic savannah (Sussman et al. 2003, Goodman et al. 2006, Gould 2006). Although L. catta occur in these varied habitats, the majority of L. catta behavioural and population ecology field studies have been conducted in riverine gallery forests (e.g. Jolly 1966, Sussman 1974, 1977, 1991, 1992, Gould 1990, 1992, 1996a,b, 1997a,b, Sauther 1993, 1994, 1998, Nakamichi \& Koyama 1997, Gould et al. 1999, 2003, Koyama et al. 2001, Jolly et al. 2002, but see Gould et al. 2009). Little research has focused on populations in other habitats, although non-gallery forest research is beginning to occur at a few sites, including sub-alpine ericoid bush (Goodman \& Langrand 1996, Goodman \& Rasolonandrasana 2001), spiny forest (Gould et al. 2009, 2011, E. Kelley unpubl. data, M. LaFleur unpubl. data) and rocky outcrop forests surrounded by anthropogenic crop production (Gould et al. 2010, A. Cameron \& L. Gould unpubl. data).

Goodman et al. (2006) suggest that Lemur catta may have evolved in arid habitats rather than gallery forests throughout southern Madagascar and, although they are found in smaller populations in these areas than in riverine gallery forests (Goodman \& Langrand 1996, Sussman et al. 2003, Jolly et al. 2006), several physical and behavioural traits support this claim. L. catta is characterized by the ability to live in areas without groundwater and with few water-based food items (Goodman et al. 2006). Furthermore, L. catta has the ability to decrease basal metabolic rate when food resource availability is low (Pereira et al. 1999). L. catta is more terrestrial than other lemur taxa, spending an average of $30 \%$ of its time on the ground (Sussman 1977). Moreover, L. catta populations can rebound from periods of decreased habitat productivity, natural disasters and extended periods of drought, as their relatively precocial life history pattern allows juveniles to reach reproductive age quickly, compared with many Haplorhine primates (Gould et al. 1999, 2003, Gould 2006, Goodman et al. 2006), and females normally give birth once per year (Jolly 1966, 1984, Sauther 1991). Thus, L. catta have been characterized as a 'weed' species because of their abilities to live in harsh environments with extremes of heat and frost, exploit a variety of high and low quality food items, and survive periods of intense water scarcity (Gould et al. 1999, 2003, Goodman et al. 2006, Gould 2006).
Lemur catta is currently categorized as Near Threatened on the IUCN Red List, because one quarter of its population has disappeared over the past 25 yr owing to substantial habitat loss (IUCN 2009). The future of this species and the endemic spiny forests are intricately tied together. Because individuals and groups disperse across dry riverbeds and open habitats (Goodman et al. 2006), L. catta serve as primary seed dispersers between different patches of spiny forest habitats, a function that can maintain seemingly fragmented pockets of forest (Ganzhorn et al. 1999, Bodin et al. 2006). Although traditional taboos on vast forest destruction may help to maintain, even unintentionally, L. catta populations at a sustainable level (Bodin et al. 2006), small spiny forest patches are highly vulnerable to anthropogenic pressures, decreasing the ability of L. catta to occupy such forests. Intensive agricultural practices, specifically tavy slash and burn forest clearance, have reduced viable habitats for $L$. catta throughout their range (Fenn \& Rebara 2003, Kelley et al. 2007). Sustained spiny forest habitat destruction limits L. catta gene flow because of the lack of small forest patches through which to disperse (Bodin et al. 2006). Thus, an improved effort to ensure the viability of L. catta populations must identify spiny forest fragments that can be effectively protected and monitored.

Long-term conservation strategies require knowledge of the resource use and behaviour of a species within its geographic range. The lack of comparable data on Lemur catta in highly diverse habitats makes current knowledge of this species' behavioural ecology incomplete (Gould 2006). Furthermore, proposed models of L. catta evolution may be better understood with a more complete account of behavioural trends in habitats in which its evolutionary history has occurred (Gould 2006). The present study provides initial data on behavioural strategies of L. Catta in spiny forest habitats and aims to engender future studies that will enhance the ability to sustain and connect genetically diverse populations of this species of lemur.

In this study, we contrast activity budgets, feeding behaviour and feeding competition of Lemur catta living in spiny forest habitats with those living in gallery forest habitats in Berenty Reserve, southern Madagascar. This comparative study provides a better understanding of simultaneous behavioural variation and reports behavioural strategies of $L$. catta in xerophytic spiny forests. We report differing behavioural strategies used in ecological settings that vary in ambient temperature, water availability, canopy cover and food type during the annual birth 
and early lactation season (September to November). This period coincides with the height of the dry season in southern Madagascar (Jolly 1984, Sauther 1994, 1998), which is characterized by very high ambient temperatures and a decrease in available drinking water (Fenn 2003). Because resource abundance is low during this period compared with the rainy season (Jolly 1984, Rasamimanana \& Rafidinarivo 1993, Sauther 1998, Sauther et al. 1999), strict reproductive seasonality in this primate means that lactating females are in need of, and competing for, scarce resources (Sauther 1993, Sauther et al. 1999).

\section{MATERIALS AND METHODS}

\section{Research site: Berenty Reserve, Madagascar}

Berenty Private Reserve, southern Madagascar, is a $240 \mathrm{~km}^{2}$ ecotourism site located on the banks of the Mandare River: $25^{\circ} 0.5^{\prime} \mathrm{S}, 4^{\circ} 18.5^{\prime} \mathrm{E}$ (Jolly 1966, Jolly et al. 2006) (Fig. 1), owned and managed by the de Heaulme family (Jolly et al. 2006). The reserve receives 400 to $520 \mathrm{~mm}$ of rainfall between November and February, comprising $70 \%$ of the annual rainfall (Pride 2003). During our study, maximum daily mid-day temperatures in the open spiny forest reached 40 to $45^{\circ} \mathrm{C}$, whereas temperatures were greater than $5^{\circ} \mathrm{C}$ cooler at the same time in the closed canopy gallery forest.

Data were collected between 4 September and 4 November 2006, corresponding to the end of the dry season in southern Madagascar and the late gestation and early to mid lactation seasons of Lemur catta. Data were collected on $L$. catta groups in 2 different ecological zones: the closed canopy Ankoba gallery forest and the xerophytic spiny forest parcel, $3 \mathrm{~km}$ from one another (Fig. 1). At Berenty, the gallery forest is a secondary forest, which contains both native and introduced plant species. Along with native Tamarindus indica trees, this habitat contains introduced Pithecellobium dulce, Azadirachta indica and Leucaena leucocephala (Soma 2006). The forest borders the Mandare River, which provides ample groundwater for large fruit trees. The river also provides drinking water for L. catta groups, even in the middle of the dry season when small puddles remain in the large riverbed. One of the reserve's main water wells is located in the middle of the forest along with small water troughs, which provide easily accessible drinking water for L. catta groups.
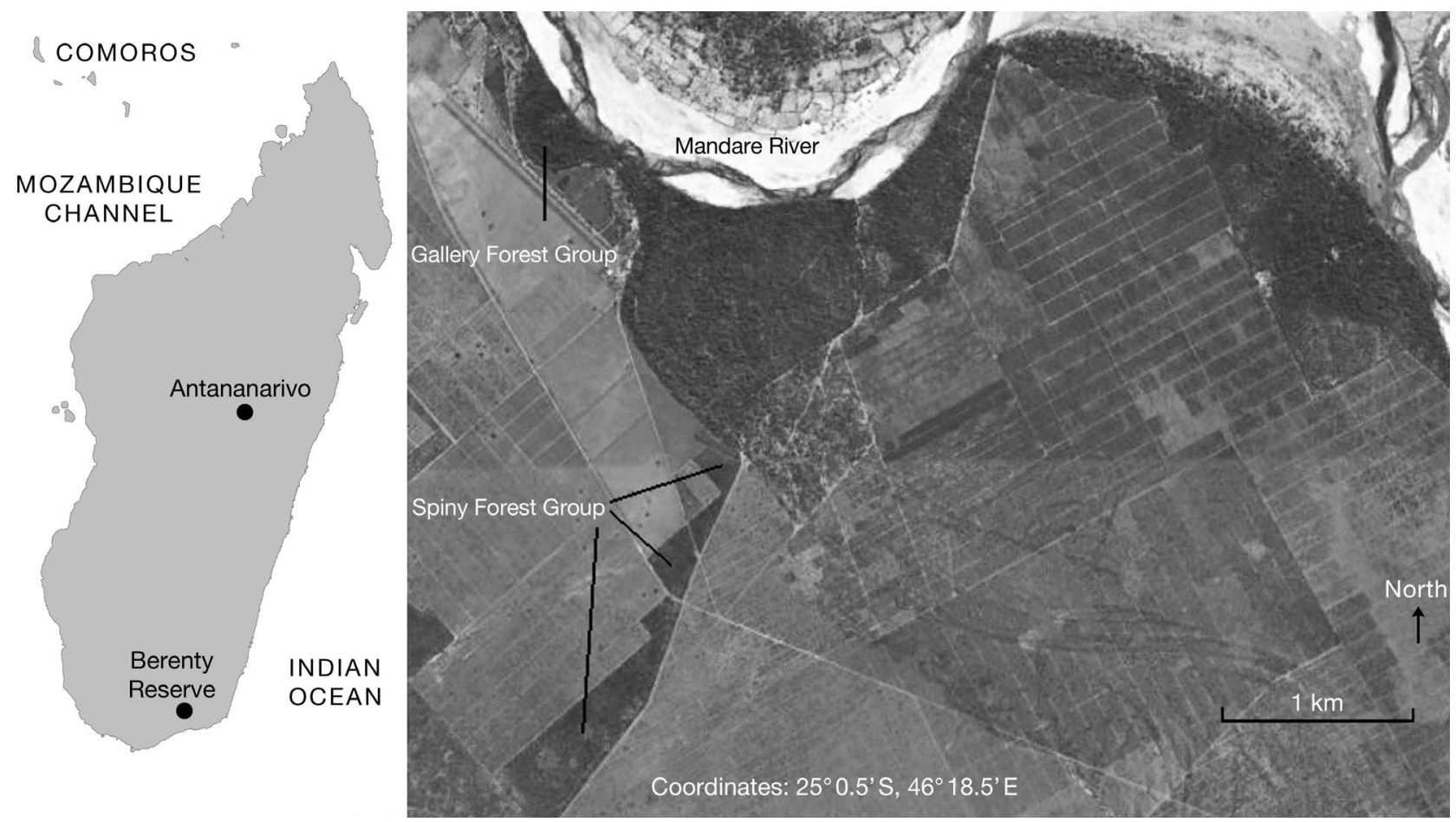

Fig. 1. Location of the study site in Madagascar (left) and within Berenty Reserve (right), with Mandare River forming the northern boundary of the reserve. The spatial proximity between the habitats of the 2 study groups (gallery forest and spiny forest) is shown; the remainder of the park is anthropogenic sisal plantation 
The entry point to the spiny forest at Berenty Reserve is marked by a nearly $7 \mathrm{~m}$ vertical hill above a scrub forest habitat, which was most likely the outer edge of the Mandare River in the past, and thus represents the end of the supply of groundwater that supports large fruiting trees (Jolly et al. 2006). No extensive studies of spiny forest ecology at Berenty Reserve currently exist, but all plant species found in the spiny forest are endemic to this specific forest type, which has evolved to survive in areas with low-nutrient soils, high temperatures during the summers and low amounts of rainfall (Grubb 2003, Fenn 2003). This forest type is dominated by the plant family Didiereaceae, especially the genus Alluaudia, which is characterized by tall yet slender trees with thorny trunks and branches, and Euphorbia candelabra, characterized by low-lying succulent vines (Fenn 2003, Grubb 2003). Gyrocarpus americanus, Agave sisalana and Opuntia vulgaris are also found in the Berenty spiny forest parcel (Charrier et al. 2007). All trees have small and exposed canopies and are significantly shorter than trees in the gallery forest at Berenty. Compared with the gallery forests, all spiny forest plants are highly exposed to solar rays, resulting in a lack of a true canopy and very little shade (Gautier \& Goodman 2003). Beginning in late October 2006, the spiny forest group periodically moved into the surrounding sisal plantations to feed on the flower buds, flowers and pith of Agave sisalana. These plants produce no canopy or shade and are characterized by tall exposed stalks with flowers at the tip.

\section{Data collection methods}

Data were collected using 15-min continuous time focal animal sampling methods (Altmann 1974). All behaviours of the focal animal were recorded and the exact start and stop time of each behaviour was noted. Ad libitum sampling was used to collect unusual occurrences, such as predation attempts on Lemur catta and inter-group conflicts between $L$. catta groups. Time, to the second, was recorded at the beginning of each behaviour. A total of 942 15 min focal animal data sessions were collected (mean no. of sessions: spiny $=54$, gallery $=84$ ), totalling $235 \mathrm{~h}$ of data collection (Table 1). Data were collected $6 \mathrm{~d}$ per week for the entire study period. Groups were observed on alternating days to ensure that hours of data collected were similar between groups and that changes in flora in either habitat
Table 1. Number of hours and sessions of data collected in each habitat on individual focal Lemur catta. Abbreviations present names of study individuals. F: female; M: male

\begin{tabular}{|lccc|}
\hline Individual & Sex & Hours & Sessions \\
\hline Spiny forest & & & \\
LOL & $\mathrm{F}$ & 14.08 & 56 \\
LUC & $\mathrm{F}$ & 13.43 & 53 \\
LIN & $\mathrm{F}$ & 14.03 & 56 \\
DRA & $\mathrm{M}$ & 12 & 48 \\
DAN & $\mathrm{M}$ & 14.16 & 56 \\
DNT & $\mathrm{M}$ & 14.26 & 57 \\
Mean & & 13.66 & 54.33 \\
Gallery forest & & & \\
KRS & $\mathrm{F}$ & 18.9 & 76 \\
MAJ & $\mathrm{F}$ & 22.4 & 90 \\
HLN & $\mathrm{F}$ & 21.8 & 87 \\
FNA & $\mathrm{F}$ & 22.1 & 88 \\
GAS & $\mathrm{M}$ & 21.2 & 85 \\
JAC & $\mathrm{M}$ & 20.7 & 83 \\
SEB & $\mathrm{M}$ & 19.9 & 80 \\
Mean & & 21.02 & 84.14 \\
\hline
\end{tabular}

were accounted for. Within study groups, the day was separated into 5 periods (morning, 7:00-10:00 $\mathrm{h}_{\text {; }}$

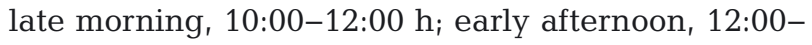
14:00 $\mathrm{h}_{\text {; }}$ mid-afternoon, 14:00-16:00 $\mathrm{h}_{\text {; }}$ late afternoon, after 16:00 h). These time periods were used to establish daily patterns of activity within and between groups and are referred to numerically as time periods 1 to 5 in the 'Results' section.

Behaviours scored in time allocation data were: feeding, foraging, locomotion, sitting, resting, social behaviour and vigilance. Resting and sitting were categorized as inactive behaviours, whereas all other behaviours were categorized as active behaviours. Nearest neighbour distance was scored as near $(<2 \mathrm{~m})$, medium $(2$ to $5 \mathrm{~m})$ and far $(>5 \mathrm{~m})$.

The total rate of agonism was calculated by dividing the total number of agonistic behaviours by the total number of hours recorded. The rate of agonism in behavioural contexts was calculated by dividing the total number of agonism events during the behaviour by the total duration of the behaviour.

Sample sizes for each group were too small to meet the assumptions of parametric statistical tests, so comparisons of behaviours between groups were assessed using non-parametric statistical tests. The Mann-Whitney U-test was used to compare data between groups. Friedman's ANOVA was used to test for variations in activity between different time periods throughout the day within the spiny forest group. Results were deemed significant at $\mathrm{p}<0.05$. 


\section{RESULTS}

\section{Time allocation}

Individuals living in the gallery forest group $(\mathrm{n}=7)$ spent a significantly greater proportion of time feeding and foraging than those in the spiny forest group $(\mathrm{n}=6)$ (Table 2). Resting occurred significantly more often in the spiny forest group than in the gallery forest group, as did sitting while awake. Lemurs in the gallery forest group engaged in significantly more social behaviour compared with the spiny forest group (Table 2). There were no significant differences in the proportion of time spent in locomotion. Cumulatively, the gallery forest group spent a greater proportion of time engaged in active behaviours compared with the gallery forest group.

To identify patterns of behaviour throughout the day, the percentage of time spent in active behaviours was analyzed within 5 separate time categories. Individuals in the gallery forest group spent significantly more time in active behaviours in the early morning, late morning, and mid-afternoon compared with individuals in the spiny forest group, whereas the groups spent similar proportions of time in active behaviours in the early and late afternoon (Table 3). There were significant differences in the proportion of active behaviours

Table 2. Lemur catta. Median (interquartile range) percentage of time allocated by lemurs to behaviours between spiny forest and gallery forest groups

\begin{tabular}{|lcccc|}
\hline Behaviour & Spiny & Gallery & $U$ & $\mathrm{p}$ \\
\hline Foraging/feeding & $14.9(5)$ & $30(4.4)$ & 0 & $<0.005$ \\
Locomotion & $7.6(1.4)$ & $7.1(2.3)$ & 17 & 0.63 \\
Resting & $52.3(3.7)$ & $34.3(5.4)$ & 0 & $<0.005$ \\
Sitting & $20.5(4.6)$ & $14.8(1.3)$ & 0 & $<0.005$ \\
Socialising & $2.6(2.9)$ & $8.8(4.25)$ & 3 & $<0.01$ \\
Active & $26.4(7.7)$ & $49.1(3.3)$ & 0 & $<0.005$ \\
Inactive & $73.6(7.6)$ & $50.9(3.3)$ & 0 & $<0.005$ \\
\hline
\end{tabular}

Table 3. Lemur catta. Median (interquartile range) percentage of time spent by lemurs in active behaviours between spiny forest and gallery forest groups in different time periods

\begin{tabular}{|lcccc|}
\hline Time period (h) & Spiny & Gallery & $U$ & $\mathrm{p}$ \\
\hline $7: 00-10: 00$ & $48(15.3)$ & $80(13)$ & 3 & $<0.005$ \\
$10: 00-12: 00$ & $15(8.3)$ & $37(6.5)$ & 3 & $<0.005$ \\
$12: 00-14: 00$ & $8(9.3)$ & $12(6)$ & 31.5 & 0.14 \\
$14: 00-16: 00$ & $23(8.8)$ & $47(13)$ & 3 & $<0.005$ \\
After $16: 00$ & $68(18.5)$ & $73(4.5)$ & 27 & 0.45 \\
\hline
\end{tabular}

between all time categories (Friedman test: $\mathrm{p}$ < 0.001, $\mathrm{n}=6$ ) among the spiny forest group only. Post hoc tests were conducted to determine which time categories were significantly different from each other. Based on an alpha value of 0.001, pairwise ranked sums were used to compare the proportion of active behaviour between time categories. There were no significant differences in the percentage of active behaviour between time periods 2,3 and 4 or between time periods 1 and 5 ( $\mathrm{p}=$ 0.001). However, Lemur catta in the spiny forest were significantly more active in the early morning and later afternoon than during the middle of the day ( $p=0.01$, Bonferonni adjustment; Table 2). This analysis shows that the spiny forest group limited active behaviours except during the earliest and latest periods of the day.

\section{Feeding and foraging behaviour}

The spiny forest group consumed 14 plant species during the study period. Two of these, Agave sisalana (sisal) and Opuntia vulgaris (Mexican prickly pear), are not native to Madagascar's spiny forest ecosystem and are found in some semi-desert habitats outside Madagascar (Felger 2000). The gallery forest group consumed a total of 11 species, the majority of which (6 out of 11) are not endemic to Madagascar. Both study groups were observed consuming fruit and leaves of Tamarindus indica and leaves of Opuntia vulgaris. T. indica are located throughout the gallery and scrub forests at Berenty but not in the spiny forest; the spiny forest group occasionally moved into the scrub forest area to feed on $T$. indica.

Individuals in both groups consumed a variety of plant parts, including mature and immature fruits and leaves, stems, leaf buds, flowers and leaves of succulent plants. Soil was consumed occasionally. The 2 groups differed significantly in their consumption of both fruits and flowers. The spiny forest group spent significantly more time eating fruit (57.1\%) compared with the gallery forest group (26.2\%) ( $U=$ $0, \mathrm{p}<0.005)$, whereas the gallery forest group spent significantly more time consuming leaves $(U=0, \mathrm{p}<$ 0.005 ; Fig. 2). The 2 groups showed significant differences in spacing while feeding on the 2 most common food items: fruit and leaves. While feeding on fruit, the spiny forest group spent a significantly greater proportion of time within $2 \mathrm{~m}$ of their nearest neighbour $(U=4, \mathrm{p}<0.05)$ and a significantly smaller proportion of their feeding time more than $5 \mathrm{~m}$ from 


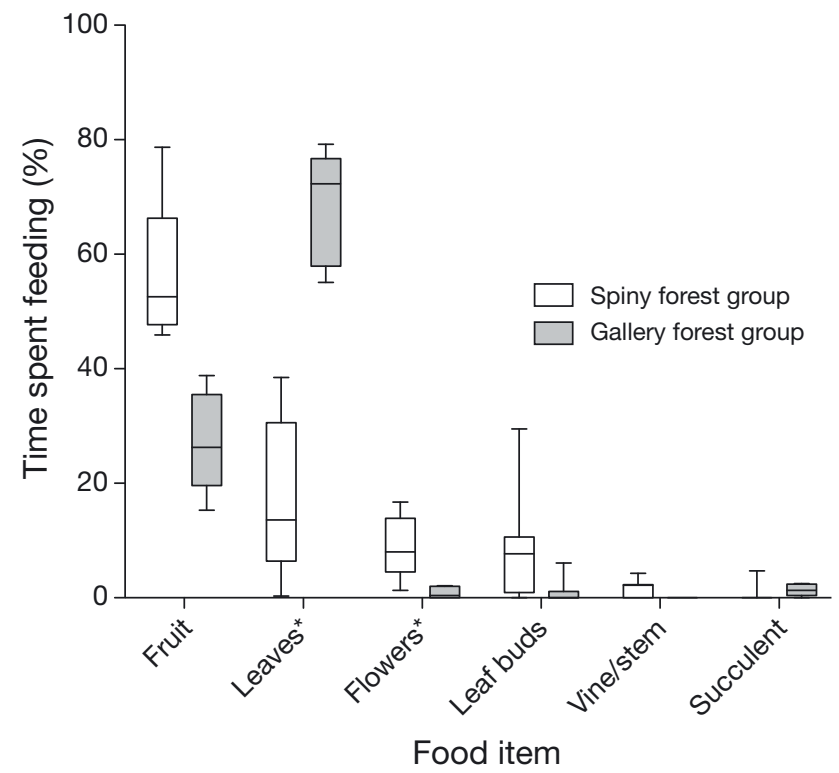

Fig. 2. Lemur catta. Proportion of time spent feeding on different plant parts. Asterisks indicate significant differences between spiny forest and gallery forest groups at $p<0.05$

a nearest neighbour compared with the gallery forest group ( $U=3, \mathrm{p}<0.05$; Fig. 3 ). The 2 groups also differed in spacing patterns while feeding on leaves. Individuals in the spiny forest group spent a significantly smaller proportion of their time in close proximity to a nearest neighbour $(U=7, \mathrm{p}<0.05)$ and a significantly greater proportion of their time far from a nearest neighbour compared with the gallery forest group $(U=6, \mathrm{p}<0.05 ;$ Fig. 3).

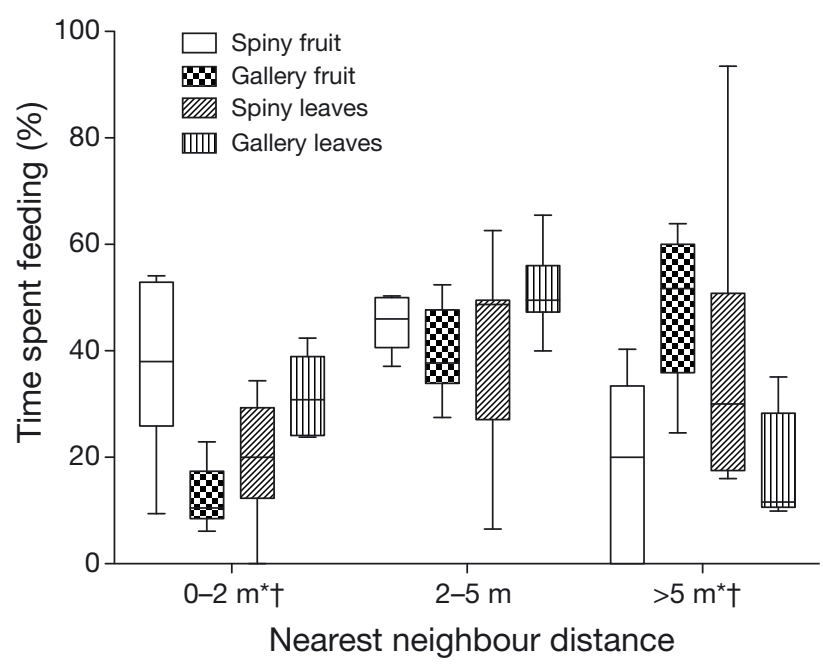

Fig. 3. Lemur catta. Proportion of time spent feeding on fruit and leaves at locations with different nearest neighbour distances. Asterisks and daggers indicate significant differences between spiny forest and gallery forest groups for fruit and leaves, respectively, at $\mathrm{p}<0.05$
The rate of total agonism was used as a baseline for comparison of feeding and social agonism. There were no significant differences in the rate of total agonism or social agonism between groups, but individuals in the spiny forest group engaged in a significantly higher rate of agonistic events per feeding hour compared with individuals in the gallery forest group ( $U=4.5, \mathrm{p}<0.05$; Fig. 4). Because of small sample sizes, the rate of feeding agonism in the spiny forest group was much greater than any other agonism rate in either group.

\section{DISCUSSION}

Primates are renowned for their ability successfully to modify behavioural strategies to cope with environmental heterogeneity (Hill et al. 2003, Brockman \& van Schaik 2005, Jones 2005). Thus, the investigation of activity patterns is central to the study of varying behavioural strategies in space and time. To sustain thermoregulation, physiological maintenance and reproductive capabilities, individuals are likely to modify activity patterns to increase energy intake and decrease energy expenditure (Whiten et al. 1987, Barton et al. 1992, Dunbar 1992, Menon \& Poirier 1996). Species seek to balance energy expenditure and intake during seasonal periods of resource scarcity (Overdorff et al. 1997, Remis 1997, Hemingway \& Bynum 2005) by using energy maximization or minimization strategies (Strier 1992). Studies of behavioural patterns of primates provide unique insights into adaptive strategies when environmental conditions challenge physiological processes. Fur-

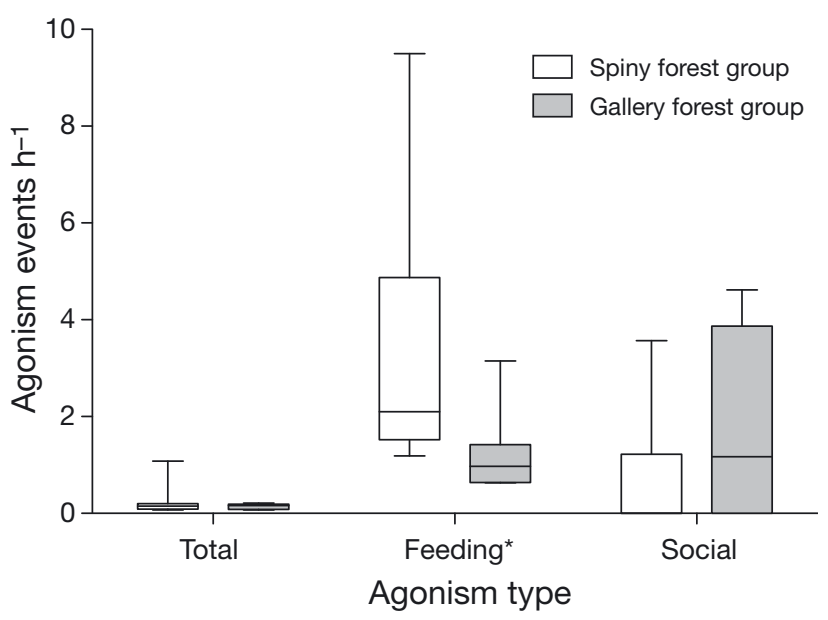

Fig. 4. Lemur catta. Rate of agonistic behaviour by lemurs. Asterisks indicate significant differences between spiny forest and gallery forest groups at $\mathrm{p}<0.05$ 
thermore, studies of resource use and social responses to locally available resources are essential to proper conservation action plans.

Although sample sizes are necessarily limited for this Near Threatened and declining species, our study suggests that Lemur catta adjust behavioural strategies between habitat types during the hot dry season. The modification of activity patterns is probably associated with ambient temperature and water availability, which we propose are limiting factors in the proportion of time spent in active behaviours by L. catta living in the spiny forest. L. catta occupying spiny forest habitats spent significantly more time consuming fruits, a highly spatially clumped and contested resource among L. catta (Sauther 1993). These factors produced a much higher rate of feeding agonism within the spiny forest group, raising intriguing questions about resource availability and quality, and their interconnected effects on L. catta feeding agonism in non-gallery forest habitats.

This study, limited to one season, indicates that $L$. catta groups can survive, reproduce and lactate in this harsh environment; however, more data are needed to understand better the behavioural and ecological parameters of $L$. catta in spiny forests throughout southwestern Madagascar (Gould 2006). Below, we discuss potential causes for modifications in behavioural patterns between L. catta groups in different habitats and provide questions that future studies of $L$. catta occupying spiny forest habitats should address.

\section{Time allocation}

The data from our study show that individuals living in the spiny forest habitat significantly reduced their time spent in active behaviours, including feeding, during the dry season. The data support the contention that Lemur catta are energy minimizers (Rasamimanana et al. 2006) and that increased levels of resting are associated with less time spent feeding (Sussman 1977). Both study groups tended towards bimodal activity patterns, with early morning and late afternoon active periods broken up by a long period of mid-day resting. Significant differences in intergroup activity patterns were primarily related to the spiny forest group's extended periods of rest during the intense heat of mid-day. This group compensated for deficiencies in mid-day foraging effort by using abbreviated yet intensive feeding periods during the early and later periods of the day.
Energy conservation strategies, which enable primates to maintain physiological processes when resource availability is low (Iwamoto \& Dunbar 1983, Barton et al. 1992, Dasilva 1992, Wright 1999, Di Fiore \& Rodman 2001) are widespread in primates (lemurs: Richard 1978, Wright 1999, Norscia et al. 2006; atelines: Milton 1980, Estrada et al. 1999, Di Fiore \& Rodman 2001; colobines: Dasilva 1992, Zhou et al. 2007). Lemur catta in the spiny forest may be able to use an energy-minimizing strategy by taking advantage of their inherently low basal metabolic rate (BMR). L. catta deviates further from the Kleiber regression line of primate BMR to body size than any other primate sampled, including other small-bodied strepsirrhines (Snodgrass et al. 2007). A low BMR slows the rate of oxidation, which in turn lowers the amount of energy processed by the body. All $L$. catta use energy-minimizing behavioural strategies because of this inherent physiological characteristic (Rasamimanana et al. 2006), but differences in resource availability between habitats likely leads to variant behavioural patterns. The spiny forest group likely maximizes energy retention by increasing time spent resting, particularly during times of high ambient temperatures and in spaces with little shade. Gould et al. (2011) found that $L$. catta select foods with relatively high levels of protein, calories and water, allowing them to compensate for time lost feeding.

Water availability is most likely a limiting factor in the allotment of active behaviour. Pre-existing reports of water content show that floral families in the spiny forests, predominantly Didiereaceae, Hernandiaceae and Euphorbiaceae, have evolved to withstand long periods of drought and high amounts of solar radiation (Fenn 2003) and, therefore, maintain lower levels of water per part than floral species in gallery forests (Grubb 2003). Water content in leaves of Tamarindus indica, the only food species shared by both groups, is positively correlated with proximity to the Mandare River (Mertl-Millhollen et al. 2006). Thus, leaves and presumably fruits from the spiny forest likely provide significantly less water needed for energy production, although the lemurs did benefit by consuming plants such as Opuntia cacti. Furthermore, the 5 plants most commonly consumed by the lemurs in the spiny forest contained significant amounts of water compared with less frequently consumed plant species (Gould et al. 2011). Moreover, individuals in the gallery forest had access to drinking water from small pools in the Mandare River and cement troughs in the Ankoba gallery par- 
cel. Thus, although groups in the spiny forest can maintain sufficient hydration by consuming plant parts (Goodman \& Langrand 1996, Gould et al. 2011), they may lose more water than the gallery forest group because of lack of access to actual standing water, increased ambient temperatures in the spiny forest, and greater solar exposure due to lack of forest canopy. Reduced water intake by spiny forest dwelling Lemur catta (compared with gallery forest dwelling conspecifics) particularly in the hot season, could have indirect effects on female reproduction, but reduced activity may be a compensatory strategy. Our study occurred during the birth and lactation period, when female $L$. catta must produce a large quantity of dilute milk to aid in survival of rapidly growing infants that suckle on demand (Power et al. 2006). A relationship between milk composition and infant thermoregulation in primates has been suggested (Tilden \& Oftedal 1997) and maternal production of dilute milk can be a reproductive survival strategy, particularly when infants must cope with high temperatures, such as in the spiny forest (Gould et al. 2011). Therefore, although no sex differences in resting time were found, lactating females could still benefit from engaging in such energy-minimizing behaviours (Rasamimanana et al. 2006) in a spiny forest habitat, because reduced activity would result in less water loss.

High ambient temperatures have been considered to have a significant influence on primate activity cycles (Macaca nemestrina, Bernstein 1972; Papio cynocephalus cynocephalus, Stelzner 1988, Pochron 2000; Papio cynocephalus ursinus, Hill 2006) because evaporative water loss in primates increases when ambient temperature rises over $30^{\circ} \mathrm{C}$ and rises sharply when temperatures exceed $40^{\circ} \mathrm{C}$ (Elizondo 1977). Stelzner (1988) has suggested that ambient temperature is a primary constraint to behaviour, as primate physiological abilities to reduce thermal stress are limited. Our study was conducted during some of the hottest months in southern Madagascar, with daily maximum temperatures in the Berenty spiny forest and surrounding matrix at times reaching over $40^{\circ} \mathrm{C}_{i}$ in December and January, temperatures would rise even further in the entire region (Jolly et al. 2006). The spiny forest group, therefore, most likely increased time spent resting in the little shade that exists in this habitat to avoid intense solar radiation and to decrease evaporative water loss. Energy-intensive behaviours, especially locomotion and foraging, took place at a fast pace and were most pronounced when temperatures were at their lowest.

\section{Foraging strategy}

Lemur catta quickly modify their feeding strategies as resources become available in gallery forest habitats (Sauther 1994, 1998, Soma 2006). The present study shows that $L$. catta alter foraging strategies between habitat types based on the available flora species within their home ranges. Furthermore, both groups fit into the dietary niche of flexible folivore/frugivore previously ascribed to L. catta (Jolly 1966, Sussman 1977, Sauther 1994, Sauther et al. 1999, Soma 2006, Gould 2006). However, the difference in selection between plant reproductive parts and leaves between groups was striking. L. catta in the spiny forest focused their foraging effort on locating small fruits, especially from Gyrocarpus americanus and Tarenna sp. and consuming leaves of succulent species such as Alluaudia procera, Aloe vahome and Opuntia vulgaris (Gould et al. 2011). Furthermore, towards the conclusion of the study, the spiny forest group spent much of its foraging time consuming flowers of Agave sisalana in fields outside of the spiny forest parcel. In contrast, L. catta in the gallery forest spent much of their foraging time consuming leaves, especially from Leucaena lercoephalla, Pithecellobium dulce and Azadirachta indicus, and consumed fruits from P. dulce and Tamarindus indica as they became available. A comparison of nutrient intake between populations living in the 2 diverse habitats would be useful to understand whether activity-minimization strategies are associated with significantly lower levels of energy and nutrient intake.

Distinctly different patterns of social spacing while foraging between the 2 groups are most likely associated with significant differences in Lemur catta foraging agonism. Contest competition is more likely to occur when primate groups feed on plant reproductive parts, which are often spatially clumped, compared with leaves, which tend to be ubiquitous throughout habitats (Wrangham 1980, van Schaik 1989). We suggest that because fruit is clumped in small tree crowns in the spiny forest, L. catta in that habitat engaged in higher levels of feeding competition while searching for these preferred food items. During the study period, $L$. catta in the gallery forest increased inter-individual spacing while consuming fruit because of increased spatial distances between fruit items in large Pithecellobium dulce and Tamarindus indica trees, and decreased individual spacing while consuming leaves, which are more plentiful and spatially clumped. Further research on L. catta feeding behaviour in spiny forest habitats can further identify patterns in relation to food type, seasonal effects on 
feeding competition, competition over specific plant part species, and the possible effect of feeding competition on differently ranked individuals.

\section{CONCLUSIONS}

We suggest that because Lemur catta successfully negotiate the ecological challenges of the spiny forest in Berenty Reserve, other populations of this species could consistently occupy spiny forest habitats if enough of the important food resources were available. Unfortunately, very little is known about the seasonal and annual patterns of resource use, distribution and activity of $L$. catta populations living in other spiny forests (although at the time of writing, one year-long study was underway in a different spiny forest region of southern Madagascar; $M$. LaFleur unpubl. data). Although population density is relatively low in non-gallery forest habitats (Sussman et al. 2003), these spiny forest groups are essential in preserving a diverse population gene pool and retaining the possibility of conserving the species outside of a small number of gallery forests near rivers. Goodman et al. (2006) have noted that ringtailed lemurs may disperse through low-resource corridors; thus maintaining primary or secondary forest throughout southern Madagascar may be vital to this species' future. Moreover, as seed dispersers, $L$. catta are vital for the survival of both gallery forests (Blumenfeld-Jones et al. 2006) and spiny forests (Bodin et al. 2006). The endemic spiny forests are vanishing at a rapid pace because of anthropogenic deforestation, and the remaining small fragments of this endemic forest type should be viewed as essential to maintaining a genetically variable primate species (Bodin et al. 2006). Thus, in the evaluation of habitats to be designated as protected for L. catta, all habitat types that contain the species, especially xerophytic spiny forest, should be considered.

Acknowledgements. We thank the de Heaulme family and the Département des Eaux et Forêts, Madagascar, for granting us permission to work at Berenty Reserve. Funding for this project was provided by a Natural Sciences and Engineering Research Council of Canada (NSERC) to L.G. All research described in this manuscript complied with protocols approved by the University of Victoria's Animal Care Committee.

\section{LITERATURE CITED}

Altmann J (1974) Observational study of behaviour: sampling methods. Behaviour 49:227-267
Barton R, Whiten A, Strum S, Bryne R, Simpson A (1992) Habitat use and resource availability in baboons. Anim Behav 43:831-844

> Bernstein I (1972) Daily activity cycles and weather influences on a pigtail monkey group. Folia Primatol 18: 390-415

Blumenfeld-Jones $\mathrm{K}$, Randriamboavonjy $\mathrm{T}$, Williams $\mathrm{G}$, Mertl-Millhollen A, Pinkus S, Rasamimanana H (2006) Tamarind recruitment and long-term stability in the gallery forest at Berenty, Madagascar. In: Jolly A, Sussman R, Koyama N, Rasamimanana H (eds) Ring-tailed lemur biology: Lemur catta in Madagascar. Springer, New York, NY, p 69-85

Bodin O, Tengo M, Norman A, Lundberg J, Elmqvist T (2006) The value of small size: loss of forest patches and ecological thresholds in southern Madagascar. Ecol Appl 16:440-451

Brockman DK, van Schaik CP (2005) Seasonality in primates: studies of living and extinct human and nonhuman primates. Cambridge University Press, New York, NY

Casse T, Milhoj A, Ranaivoson S, Randriamanarivo J (2004) Causes of deforestation in southwestern Madagascar: What do we know? For Policy Econ 6:33-48

Charrier A, Hladik A, Simmen B (2007) Stratégie alimentaire et dominance des femelles Propithèque de Verreauxi (Propithecus v. verreauxi) dans la forêt à Didiereaceae du sud de Madagascar. Rev Ecol Terre Vie 62:257-263

$>$ Dasilva G (1992) The western black-and-white colobus as a low-energy strategist: activity budgets, energy expenditure and energy intake. J Anim Ecol 61:79-91

> Di Fiore A, Rodman P (2001) Time allocation patterns in lowland wooly monkeys (Lagothrix lagotricha poeppigii) in a neotropical terra firma forest. Int J Primatol 22:449-480

- Dunbar R (1992) Time: a hidden constraint on the behavioural ecology of baboons. Behav Ecol Socioecol 31: $35-49$

Elizondo R (1977) Temperature regulation in primates: In: Robertshaw A (ed) International review of physiology, Vol. 5. University Park Press, Baltimore, MD

Estrada A, Juan-Solano S, Martinez T, Coates-Estrada R (1999) Feeding and general activity patterns of a howler monkey (Alouatta palliata) troop living in a forest fragment at Los Tuxtlas, Mexico. Am J Primatol 48:167-183

Felger R (2000) Flora of the Gran Desierto and Rio Colorado of northwestern Mexico. University of Arizona Press, Tucson, AZ

Fenn M (2003) The spiny forest ecoregion. In: Goodman S, Benstead J (eds) The natural history of Madagascar. University of Chicago Press, Chicago, IL

> Fenn M, Rebara F (2003) Present migration tendencies and their impacts in Madagascar spiny forest ecoregion. Nomad People 7:123-137

> Ganzhorn J, Fietz J, Rakatovao E, Schwab D, Zinner D (1999) Lemurs and the regeneration of dry deciduous forest in Madagascar. Conserv Biol 13:794-804

Gautier L, Goodman SM (2003) Introduction to the flora of Madagascar. In Goodman S, Benstead J (eds) The natural history of Madagascar. University of Chicago Press, Chicago, IL, p 229-256

> Goodman S, Langrand O (1996) A high mountain population of the ring-tailed lemur (Lemur catta) on the Andringitra Massif, Madagascar. Oryx 30:259-268 
Goodman S, Rasolonandrasana B (2001) Elevational zonation of birds, insectivores, rodents, and primates on the slopes of the Andringitra Massif, Madagascar. J Nat Hist 3(2):285-305

Goodman S, Rakotoarisoa S, Wilme L (2006) The distribution and biogeography of the ring-tailed lemur (Lemur catta). In: Jolly A, Sussman R, Koyama N, Rasamimanana H (eds) Ring-tailed lemur biology: Lemur catta in Madagascar. Springer, New York, NY, p 3-15

Gould L (1990) The social development of free-ranging infant Lemur catta at Berenty Reserve, Madagascar. Int J Primatol 11:297-318

Gould L (1992) Alloparenting care in free-ranging Lemur catta at Berenty Reserve, Madagascar. Folia Primatol 58: 72-83

Gould L (1996a) Vigilance behaviour during the birth and lactation season in naturally occurring ring-tailed lemurs. Int J Primatol 17:331-347

Gould L (1996b) Male-female affiliative relationships in naturally occurring ring-tailed lemurs (Lemur catta) at the Beza-Mahafaly Reserve, Madagascar. Am J Primatol 39: 63-78

Gould L (1997a) Affiliative relationships between adult males and immature group members in naturally occurring ring-tailed lemurs (Lemur catta). Am J Primatol 103: 163-171

> Gould L (1997b) Intermale affiliative behaviour in ringtailed lemurs (Lemur catta) at the Beza-Mahafaly Reserve, Madagascar. Primates 38:15-30

Gould L (2006) Lemur catta ecology: what we know and what we need to know. In: Gould L, Sauther M (eds) Lemurs: ecology and adaptation. Springer, New York, NY, p 255-274

Gould L, Sussman R, Sauther M (1999) Natural disasters and primate populations: The effects of a 2-year drought on a naturally occurring population of ring-tailed lemurs (Lemur catta) in southwestern Madagascar. Int J Primatol 20:69-84

Gould L, Sussman R, Sauther M (2003) Demographic and life history patterns in a population of ring-tailed lemurs (Lemur catta) at Beza Mahafaly Reserve, Madagascar: a 15-year perspective. Am J Phys Anthropol 120:182-194

Gould L, Constabel P, Mellway R, Rambeloarivony H (2009) Condensed tannin intake in spiny-forest-dwelling Lemur catta at Berenty Reserve, Madagascar, during reproductive periods. Folia Primatol 80:249-263

Gould L, Cameron A, Gabriel D (2010) Lemurs on the rocks: preliminary study of ring-tailed lemur demography, habitat use, and feeding ecology in rocky outcrop habitat in south-central Madagascar. Am J Phys Anthropol Suppl 50:114

Gould L, Power ML, Ellwanger N, Rambeloarivony H (2011) Feeding behaviour and nutrient intake in spiny forestdwelling ring-tailed lemurs (Lemur catta) during early gestation and early to mid-lactation periods: compensating in a harsh environment. Am J Phys Anthropol 145: 469-479

Green GM, Sussman RW (1990) Deforestation history of the eastern rainforests of Madagascar from satellite images. Science 248:212-215

Grubb P (2003) Interpreting some outstanding features of the flora and vegetation of Madagascar. Perspect Plant Ecol Evol Syst 6:125-146

Hemingway C, Bynum N (2005) The influence of seasonality on primate diet and ranging. In: Brockman D, van Schaik
C (eds) Seasonality in primates: studies of living and extinct human and non-human primates. Cambridge University Press, New York, NY, p 57-104

> Hill RA (2006) Thermal constraints on activity scheduling and habitat choice in baboons. Am J Phys Anthropol 129: 242-249

Hill RA, Barrett L, Gaynor D, Ingrill T, Dixon P, Payne H, Henzi SP (2003) Day length, latitude and behavioural (in)flexibility in baboons (Papio cynocephalus ursinus). Behav Ecol Sociobiol 53:278-286

IUCN (2009) IUCN Red List of Threatened Species. Version 2009.2. www.iucnredlist.org

Iwamoto T, Dunbar R (1983) Thermoregulation, habitat quality, and the behavioural ecology of gelada baboons. J Anim Ecol 52:357-366

Jolly A (1966) Lemur behaviour: a Madagascar field study. University of Chicago Press, Chicago, IL

Jolly A (1984) The puzzle of female feeding priority. In: Small M (ed) Female primates: studies by women primatologists. Alan R. Liss, New York, NY, p 179-215

Jolly A, Dobson A, Rasamimanana H, Walker J, O'Connor S, Solberg M, Perel V (2002) Demography of Lemur catta at Berenty Reserve, Madagascar: effects of troop size, habitat and rainfall. Int J Primatol 23:327-353

Jolly A, Koyama N, Rasamimanana H, Crowley H, Williams G (2006) Berenty Reserve: a research site in southern Madagascar. In: Jolly A, Sussman R, Koyama N, Rasamimanana H (eds) Ring-tailed lemur biology: Lemur catta in Madagascar. Springer Press, New York, NY, p 32-42

Jones C (2005) Behavioural flexibility in primates: causes and consequences. Springer, Chicago, IL

Kelley EA, Sussman RW, Muldoon KM (2007) The status of lemur species at Antserananomby: an update. Primate Conserv 22:71-77

Koyama N, Nakamichi M, Oda R, Ichino S, Miyamoto N, Takahata Y (2001) A 10-year summary of reproductive parameters for ring-tailed lemurs at Berenty, Madagascar. Primates 42:1-14

Menon S, Poirier F (1996) Lion-tailed macaques (Macaca silenus) in a disturbed forest fragment: activity patterns and time budgets. Int J Primatol 17:969-985

Mertl-Millhollen AS, Rambeloarivony H, Miles W, Kaiser VA and others (2006) The influence of tamarind tree quality and quantity on Lemur catta behaviour. In: Jolly A, Sussman R, Koyama N, Rasamimanana H (eds) Ringtailed lemur biology: Lemur catta in Madagascar. Springer, New York, NY, p 102-118

Milton K (1980) The foraging strategy of howling monkeys: a study in primate economics. Columbia University Press, New York, NY

> Myers N, Mittermeier R, Mittermeier C, Gustavo A, Kent J (2000) Biodiversity hotspots for conservation priorities. Nature 403:853-858

Nakamichi M, Koyama N (1997) Social relationships among ring-tailed lemurs (Lemur catta) in two free-ranging troops at Berenty Reserve, Madagascar. Int J Primatol 18: 73-93

Norscia I, Carrai V, Borgognini-Tarli S (2006) Influence of dry season and food quality on behaviour and feeding strategy of Propithecus verreauxi in Kirindy, Madagascar. Int J Primatol 27:1001-1022

Overdorff DJ, Strait SG, Telo A (1997) Seasonal variation in activity and diet in a small bodied folivorous primate, Hapalemur griseus, in southeastern Madagascar. Am J Primatol 43:211-223 
Pereira M, Strohecker R, Cavigelli S, Hughes C, Pearson D (1999) Metabolic strategy and social behaviour in Lemuiridae. In: Rakotosamimanana B, Rasamimanana H, Ganzhorn J, Goodman S (eds) New directions in lemur studies. Kluwer Academic, New York, NY, p 93-118

Pochron S (2000) Sun avoidance in yellow baboons (Papio cynocephalus cynocephalus) of Ruaha Park, Tanzania: variations with season, behaviour, and weather. Int J Meteorol 44:141-147

Power M, Tilden C, Oftedal O (2006) Patterns of milk composition in prosimian primates. Am J Primatol 68(Suppl 1):131

Pride E (2003) The socio-endocrinology of group size in Lemur catta. PhD dissertation, Princeton University, Princeton, NJ

Rasamimanana H, Rafidinarivo E (1993) Feeding behaviour of Lemur catta females in relation to their physiological state. In: Kappeler P, Ganzhorn J (eds) Lemur social systems and their ecological basis. Plenum Press, New York, NY, p 271-295

Rasamimanana H, Andrianome V, Ramibeloarivony H, Pasquet $P$ (2006) Male and female ring-tailed lemurs' energetic strategy does not explain female dominance. In: Jolly A, Sussman R, Koyama N, Rasimimanana H (eds) Ring-tailed lemur biology: Lemur catta in Madagascar. Springer, New York, NY, p 271-295

Remis E (1997) Western lowland gorillas (Gorilla gorilla gorilla) as seasonal frugivores: use of variable resources. Am J Primatol 43:87-109

Richard A (1978) Behavioral variation: case study of Malagasy lemur. Associated University Press, Cranburry, NJ

Sauther ML (1991) Reproductive behaviour of free-ranging Lemur catta at Beza Mahafaly Special Reserve, Madagascar. Am J Phys Anthropol 84:463-477

Sauther ML (1993) Resource competition in wild populations of ring-tailed lemurs (Lemur catta): implications for female dominance. In: Kappeler P, Ganzhorn J (eds) Lemur social systems and their ecological basis. Plenum Press, New York, NY, p 135-152

Sauther ML (1994) Wild plant use by pregnant and lactating ring-tailed lemurs, with implications for early hominid foraging. In: Etkin N (ed) Eating on the wild side. University of Arizona Press, Tucson, AZ, p 240-256

Sauther ML (1998) Interplay of phenology and reproduction in ring-tailed lemurs: implications for ring-tailed lemur conservation. Folia Primatol 69:309-320

Sauther ML, Sussman RW, Gould L (1999) The socioecology of the ring-tailed lemur: thirty-five years of research. Evol Anthropol 8:120-132

Scott D, Brown D, Hahood S, Denton B, Silburn A, Rakatondraparany F (2006) The impacts of forest clearance on lizards, small mammals and bird communities in the arid spiny forest, southern Madagascar. Biol Conserv 127: 72-87
Snodgrass J, Leonard W, Robertson M (2007) Primate biometrics: an evolutionary perspective. In: Ravosa $M$, Dagosto M (eds) Primate origins: adaptations and evolution. Springer, New York, NY, p 703-737

Soma T 2006. Tradition and novelity: Lemur catta feeding strategy on introduced tree species at Berenty Reserve. In: Jolly A, Sussman R, Koyama N, Rasamimanana H (ed) Ring-tailed lemur biology: Lemur catta in Madagascar. Springer Press, New York, NY, p 141-159

Stelzner J (1988) Thermal effects on movement patterns of yellow baboons. Primates 29:91-105

- Strier KB (1992) Ateline adaptations: behavioral strategies and ecological constraints. Am J Phys Anthropol 88: 515-524

Sussman RW (1974) Ecological distinctions in overlapping Lemur species. In: Martin R, Doyle G, Walker A (eds) Prosimian biology. Duckworth Publishing, London, p 75-108

Sussman RW (1977) Feeding behaviour of Lemur catta and Lemur fulvus. In: Clutton-Brock T (ed) Primate ecology: studies of feeding and ranging behaviour in lemurs, monkeys, and apes. Academic Press, New York, NY p 1-36

> Sussman RW (1991) Demography and social organization of free-ranging Lemur catta in the Beza Mahafaly Reserve, Madagascar. Am J Phys Anthropol 84:43-58

Sussman RW (1992) Male life history and intergroup mobility among ring-tailed lemurs. Int J Primatol 13:395-413

> Sussman RW (2002) Adaptive array of lemurs of Madagascar revisited. Evol Anthropol 11:75-78

Sussman RW, Green G, Portman I, Andrianasolondraibe O, Ratsirarson J (2003) A survey of the habitat of Lemur catta in southwestern and southern Madagascar. Primate Conserv 19:32-57

Tilden CD, Oftedal OT (1997) Milk composition reflects patterns of maternal care in prosimian primates. Am J Primatol 41:195-211

van Schaik C (1989). The ecology of social relationships amongst female primates. In: Standen V, Foley R (eds) Comparative socioecology: the behavioural ecology of humans and other mammals. Blackwell Scientific Publications, Boston, MA, p 195-218

Wells D (2003) The spiny forest ecoregion. In: Goodman S, Benstead J (eds) A natural history of Madagascar. University of Chicago Press, Chicago, IL, p 384-389

Whiten A, Byrne RW, Henzi SP (1987) The behavioural ecology of mountain baboons. Int J Primatol 8:367-388

Wrangham RW (1980) An ecological model of femalebonded primate groups. Behaviour 75:262-300

Wright PC (1999) Lemur traits and Madagascar ecology. Yearb Phys Anthropol 110(Suppl. 29):31-72

Zhou Q, Ii F, Huang C, Li M, Ren B, Luo B (2007) Seasonal variation in the activity patterns and time budgets of Trachypithecus francoisi in the Nonggang Nature Reserve, China. Int J Primatol 28:657-671 
Appendix. Table A1. Plant species eaten by spiny forest and gallery forest groups of Lemur catta. A number of individuals also selected soil off the ground as a supplementary part of their diet

\begin{tabular}{|c|c|c|}
\hline Taxonomic family & Species & Food type \\
\hline \multicolumn{3}{|l|}{ Spiny forest } \\
\hline Agave $^{\mathrm{a}}$ & Agave sisalana & Succulent leaves \\
\hline Burserceae & Commiphora sp. & Leaf buds \\
\hline Boraginaceae & Cordia caffra & Leaves \\
\hline Cactaceae $^{\mathrm{a}, \mathrm{b}}$ & Opuntia sp. & Succulent leaves \\
\hline Caesalpiniodae $^{\mathrm{b}}$ & Tamarindus indica & Fruit, leaves, leaf buds \\
\hline Capparaceae & Maeura folfimus & Leaves \\
\hline Didiereaceae & Alluadia procera & Flowers, leaves, fruit \\
\hline Euphorbia & Euphorbia sp. & Stems \\
\hline Hernandiaceae & Gyrocarpus americanus & Flowers, leaves, fruit \\
\hline Liliaceae & Aloesp. & Succulent leaves \\
\hline Mimosoideae & Acacia sp. & Leaves \\
\hline Ribiacae & Tarenna sp. & Fruit \\
\hline Salvadoraceae & Azima tetracantha & Leaves, flowers \\
\hline Salvadoraceae & Salvadora augustifolia & $\begin{array}{l}\text { Fruit, leaf buds } \\
\text { Soil }\end{array}$ \\
\hline \multicolumn{3}{|l|}{ Gallery forest } \\
\hline Cactaceae $^{a, b}$ & Opuntia sp. & Succulent leaves \\
\hline Caesalpiniodeae $^{\mathrm{b}}$ & Tamarindus indica & Leaves, leaf buds, fruit \\
\hline Capparaceae $^{\mathrm{a}}$ & Cordia sp. & Leaves and fruit \\
\hline Capparaceae & Craveta excelsa & Flowers \\
\hline Capparidaceae & Cadaba virgata & Leaves \\
\hline Convolvulacea $^{\mathrm{a}}$ & Iporea robbers & Flowers \\
\hline Mimosoideae & Acacia rovumae & Leaves \\
\hline Mimosoideae $^{a}$ & Leucaena lercoephalla & Leaves \\
\hline Mimosoideae $^{\mathrm{a}}$ & Pithecellobium dulce & Fruit, flowers \\
\hline \multirow[t]{2}{*}{ Meleaceae $^{a}$} & Azadirachta indica & Leaves \\
\hline & & Soil \\
\hline
\end{tabular}

Editorial responsibility: Phillip Stephens,

Durham, UK
Submitted: May 25, 2010; Accepted: June 14, 2011 Proofs received from author(s): September 16, 2011 